\title{
Efek Penambahan Deksametason 5 mg pada Bupivakain 0,5\% terhadap Mula dan Lama Kerja Blokade Sensorik Anestesia Epidural untuk Operasi Ortopedi Ekstremitas Bawah
}

\author{
Irwan, ${ }^{1}$ Erwin Pradian, ${ }^{2}$ Tatang Bisri ${ }^{2}$ \\ ${ }^{1}$ Rumah Sakit TNI AU Dr. Salamun Bandung, ${ }^{2}$ Departemen Anestesiologi dan Terapi Intensif \\ Fakultas Kedokteran Universitas Padjadjaran/Rumah Sakit Dr. Hasan Sadikin Bandung
}

\begin{abstract}
Abstrak
Operasi ortopedi ekstremitas bawah dengan anestesia regional epidural memiliki kelemahan yaitu mula kerja yang lama. Penelitian ini bertujuan melihat efek penambahan $5 \mathrm{mg}$ deksametason pada bupivakain 0,5\% terhadap mula kerja dan lama kerja blokade sensoris. Penelitian prospektif eksperimental menggunakan uji klinis acak buta ganda pada 32 pasien dengan American Society of Anesthesiologist (ASA) I-II yang menjalani operasi ortopedi ekstremitas bawah dengan anestesi epidural di RSUP Dr. Hasan Sadikin Bandung pada Februari-Mei 2014. Pengambilan sampel dilakukan secara consecutive sampling dan random blok permutasi. Kelompok I, deksametason 5 mg ditambahkan ke dalam bupivakain 0,5\% 15 mL. Kelompok II, bupivakain 0,5\% ditambah $\mathrm{NaCl}$ 0,9\% $15 \mathrm{~mL}$. Hasil penelitian diuji secara statistika menggunakan uji-t dan Uji Mann-Whitney. Hasil penelitian menunjukkan mula kerja blokade sensorik kelompok I tidak lebih cepat, yaitu 13,56 menit dibanding dengan kelompok II, yaitu 14,31 menit ( $\mathrm{p}=0,27)$. Lama kerja blokade sensorik kelompok I lebih lama, yaitu 399,81 menit dibanding dengan kelompok II, yaitu 227,43 menit $(\mathrm{p}=0,00)$. Simpulan, penambahan deksametason $5 \mathrm{mg}$ pada bupivakain $0,5 \% 15 \mathrm{~mL}$ tidak mempercepat mula kerja blokade sensorik tetapi memperpanjang lama kerja blokade sensorik bupivakain $0,5 \%$ yang diberikan secara epidural.
\end{abstract}

Kata kunci: Anestesi epidural, blokade sensorik, bupivakain, deksametason, lama kerja, mula kerja

\section{Effect of Dexamethasone $5 \mathrm{mg}$ Addition to Bupivacaine $0.5 \%$ on Onset and Duration of Sensory Blockade in Epidural Anesthesia for Lower Extremity Orthopedic Surgery}

\begin{abstract}
Lower extremity orthopedic surgery performed with regional epidural anesthesia was still have weakness which is long onset of time. This study was conducted to determine the onset time and duration time of sensory blockade epidural anesthesia between the use of dexamethasone $5 \mathrm{mg}$ addition to $0.5 \%$ bupivacaine for lower limb orthophedic surgery. The study was using randomized controlled blind method on 32 ASA III patients undergoing lower limb orthopedic surgery under epidural anesthesia. Consecutive sampling and random allocation of block of permutation groups was applied. In group I, dexamethasone $5 \mathrm{mg}$ was added to bupivacaine $0.5 \% 15 \mathrm{~mL}$ while in group II $\mathrm{NaCl} 1 \mathrm{~mL}$ was added to bupivacaine $0.5 \% 15 \mathrm{~mL}$. The results were statistically tested using t-test and Mann-Whitney test. It was shown that the onset time of sensory blockade was not significantly faster when dexamethasone was added in bupivacaine $0.5 \%, 13.56$ minutes versus 14.31 minutes $(\mathrm{p}=0.27)$. The duration time of sensory blockade in dexamethasone in bupivacaine $0.5 \%$ group was longer 399.81 minutes, compared to the bupivacaine $0.5 \%$ group, 227.43 minutes $(\mathrm{p}=0.00)$. In conclusions, the addition of dexamethasone $5 \mathrm{mg}$ to bupivacaine $0.5 \% 15 \mathrm{~mL}$ does not produced faster onset time. However, the duration sensory blockade time is longer than bupivacaine $0,5 \% 15 \mathrm{~mL}$ is used
\end{abstract}

Key words: Bupivacaine, dexamethasone, duration time, epidural anesthesia, onset, sensory blockade

Korespondensi: Irwan, dr., SpAn. M. Kes, Rumah Sakit TNI AU Dr. Salamun Bandung, Jalan Ciumbuleuit No.203, Jawa Barat 40142, Telp. (022) 2032090, Mobile 081344225697, Email irwanmed93@gmail.com 


\section{Pendahuluan}

Anestesia epidural merupakan teknik anestesi yang menempatkan obat anestesia lokal di dalam ruang epidural. Keuntungan dari teknik anestesia regional khususnya epidural, adalah relatif lebih murah, pengaruh sistemik lebih kecil, menghasilkan analgesia yang adekuat, mencegah respons stres lebih sempurna, mengurangi jumlah perdarahan intraoperatif, dan juga dapat digunakan untuk penanganan nyeri pascabedah. Salah satu kelemahan dari anestesia regional, khususnya pada anestesia epidural yang menggunakan bupivakain murni adalah mula kerja lama dan lama kerja terbatas, dan kita sering dihadapkan pada operasi yang harus dilakukan segera atau membutuhkan waktu pembedahan yang lama. ${ }^{1,2}$

Selama ini sering dilakukan penambahan adjuvan terhadap obat anestesia lokal yang bertujuan mempercepat onset/mula kerja dan memperpanjang efek analgesia obat anestesia lokal yang dipergunakan untuk anestesia epidural. Sampai saat ini terdapat bermacammacam adjuvan yang digunakan pada anestesi regional antara lain golongan opioid, klonidin, neostigmin, hialuronidase, bikarbonat, serta midazolam. ${ }^{2-4}$

Penggunaan opioid dan juga obat-obat lain sebagai agen adjuvan sering menimbulkan efek samping yang tidak diinginkan terutama pada depresi napas, mual muntah, dan pruritus. Hal inilah yang memacu peneliti untuk meneliti obat-obatan lain yang dapat digunakan sebagai adjuvan pada anestesi epidural. ${ }^{3}$

Definisi dari anestesi lokal adalah hilangnya sensasi suatu area di tubuh yang disebabkan depresi dari eksitasi akhir saraf atau inhibisi proses konduksi impuls pada nervus perifer. Anestesia lokal akan memberikan efek berupa hilangnya sensasi tanpa disertai kehilangan kesadaran, hal tersebut merupakan perbedaan dasar antara anestesia lokal dibanding dengan anestesia umum. ${ }^{3}$

Bupivakain merupakan obat anestesia lokal golongan amino amid yang telah lama serta banyak digunakan untuk anestesia regional. Bupivakain 0,5\% isobarik merupakan jenis anestesia lokal yang banyak digunakan untuk anestesia epidural dan dapat mengakibatkan toksisitas sistemik bila terjadi penyuntikan intravena atau absorbsi sistemik dari rongga epidural. Manifestasi toksisitas yang pertama kali muncul terjadi pada sistem saraf pusat seperti kejang tonik klonik. Hal ini dapat terjadi pada saat kecelakaan penyuntikan bupivakain 2,5 mg yang masuk pembuluh darah arteri. Efek kardiotoksik membutuhkan konsentrasi obat yang lebih tinggi di dalam plasma, yaitu 4-7 kali dosis yang dapat menyebabkan kejang tonik klonik. ${ }^{4-6}$

Deksametason merupakan kortikosteroid golongan glukokortikoid yang memiliki efek anti-inflamasi yang paling kuat. Mekanisme pasti dari efek analgesia deksametason belum dapat dijelaskan. Pemberian deksametason akan menekan pembentukan bradikinin serta pelepasan neuropeptida dariujung-ujung saraf. Kedua hal itu dapat menimbulkan rangsangan nyeri terhadap jaringan yang mengalami inflamasi. Penekanan produksi prostaglandin oleh deksametason dapat menghasilkan efek analgesia melalui penghambatan pada sintesis jalur siklooksigenase pada jaringan perifer. Deksametason juga dapat menekan mediator inflamasi seperti tumor necrosis factor- $\alpha$ (TNF- $\alpha$ ) dan interleukin-6 (IL-6). ${ }^{3-5}$

\section{Subjek dan Metode}

Penelitian ini dilakukan secara prospektif eksperimental dengan menggunakan uji klinis acak buta ganda (double blind randomized controlled trial) pada 32 orang pasien dengan American Society of Anesthesiologist (ASA) I-II yang menjalani operasi ortopedi ekstremitas bawah dengan anestesia epidural di kamar bedah sentral RSUP Dr. Hasan Sadikin Bandung pada periode Februari-Mei 2014. Pengambilan sampel pasien dilakukan secara consecutive sampling dan alokasi subjek ke dalam salah satu kelompok dilakukan secara random blok permutasi. Berdasar atas perhitungan statistik dengan rumus penentuan besar sampel untuk penelitian analitis katagorik numerik tidak berpasangan untuk menguji perbedaan ratarata dengan taraf kepercayaan 95\% dan juga kuasa uji (power test) 95\%, diperoleh total 
sampel 32 pasien. Analisis statistik untuk data numerik nilai $\mathrm{p}$ dihitung berdasarkan uji-t tidak berpasangan apabila data berdistribusi normal, sedangkan analisis untuk data tidak berdistribusi normal menggunakan Uji MannWhitney. Untuk data kategorik $\mathrm{p}$ dihitung berdasarkan uji chi-kuadrat, dengan alternatif lain mempergunakan Uji Kolmogorov Smirvov, nilai statistika bermakna bila $\mathrm{p}<0,05$. Kriteria inklusi yaitu pasien yang menjalani operasi ortopedi ekstremitas bawah, pasien dengan status fisik ASA I-II, usia 18-60 tahun, serta pasien bersedia dilakukan anestesia epidural. Kriteria eksklusi yaitu pasien dengan infeksi di sekitar tempat penyuntikan obat epidural, gangguan pembekuan darah, dan hipovolemia berat. Kriteria pengeluaran yaitu bila terjadi kegagalan blok epidural setelah ditunggu lebih dari 30 menit dan operasi lebih dari 6 jam.

Setelah mendapat persetujuan dari Komite Etik Penelitian Kesehatan Fakultas Kedokteran Unpad/RSHS Bandung, dilakukan pemilihan subjek penelitian sesuai dengan kriteria inklusi dan tidak termasuk dalam kriteria eksklusi, kemudian dilakukan penjelasan kepada pasien dan juga keluarganya mengenai prosedur yang akan dialami oleh pasien selama mengikuti penelitian dan menandatangani persetujuan (informed consent).

Pasien dibagi menjadi dua kelompok yang terdiriatas 16 pasien masing-masingkelompok. Kelompok A diberikan deksametason $5 \mathrm{mg}$ dalam bupivakain sebanyak 0,5\%-15 mL. Kelompok B diberi $\mathrm{NaCl}$ 0,9\% $1 \mathrm{~mL}$ dalam bupivakain sebanyak 0,5\%-15 mL. Kemudian pasien dibawa ke kamar operasi, lalu dipasang alat-alat pantau berupa tensimeter automatis, pulse oksimetri, laju nadi, laju napas, serta elektrokardiografi (EKG). Selanjutnya, pasien diinfus mempergunakan jarum 18G, diberi Ringer laktat $15 \mathrm{~mL} / \mathrm{kgBB} 20$ menit sebelum suntikan jarum epidural. Pada kulit tempat penyuntikan epidural dilakukan tindakan aseptik memakai betadin serta alkohol $70 \%$. Jarum epidural tuohy 18 G ditusukkan di garis tengah intervertebralis L3-4 sampai ke ruang epidural dengan posisi pasien tidur miring (lateral dekubitus) setelah sebelumnya disuntikkan anestetik lokal lidokain 2\% dan dengan bevel jarum menghadap ke kaudal. Ruang epidural diidentifikasi dengan teknik loss of resistance menggunakan udara.

Kateter epidural dimasukkan sedalam $3 \mathrm{~cm}$, lalu dilakukan pemberian test dose dengan lidokain 2\% $3 \mathrm{~mL}$ dalam adrenalin 1:200.000. Setelah itu, pasien dikembalikan dalam posisi terlentang dengan kepala dipasang bantal dan diberikan oksigen 2-3 L/menit melalui kanul. Setelah ditunggu selama 5 menit, disuntikkan obat penelitian dengan kecepatan 2-3 detik/ $\mathrm{mL}$ sampai jumlahnya mencapai $15 \mathrm{~mL}$. Mula kerja blokade sensorik diukur dengan tes pinprick memakai jarum yang diukur setiap satu menit. Lama blok sensorik dinilai setiap jam setelah obat penelitian dimasukkan dan tetap dilanjutkan walaupun operasi telah selesai, penelitian berakhir pada saat pasien pertama sekali mengeluh nyeri dengan nilai numeric rating scale (NRS) 3. Bila selama operasi berlangsung pasien telah mengeluh nyeri dengan nilai NRS 3 maka akan diberikan obat bupivakain $0,5 \%$ sebanyak $35 \mathrm{mg}$ melalui kateter epidural. Operasi dimulai jika analgesia sudah mencapai L1.

Tekanan darah, denyut jantung, laju napas, dan juga saturasi oksigen perifer diukur tiap 2,5 menit pada 30 menit pertama setelah obat anestesia disuntikkan ke dalam rongga epidural, kemudian setiap lima menit selama operasi berlangsung, setiap 15 menit selama pasien dirawat di ruang pemulihan dan juga terakhir diukur setiap satu jam selama pasien dipindahkan ke ruang perawatan. Data lain yang diobservasi adalah kejadian hipotensi, bradikardia, dan mual muntah.

Bila terjadi hipotensi diberikan efedrin $5 \mathrm{mg}$ intravena. Bila terjadi bradikardia diberikan sulfas atropin 0,1 mg intravena dan bila terjadi mual muntah diberikan ondansetron $4 \mathrm{mg}$ intravena.

\section{Hasil}

Telah dilakukan penelitian penambahan obat deksametason $5 \mathrm{mg}$ pada bupivakain 0,5\% dibanding dengan bupivakain $0,5 \%$ murni terhadap mula kerja blok dan lama kerja blok pada 32 pasien yang menjalani operasi ortopedi 
Tabel 1 Karakteristik Pasien Dua Kelompok Penelitian

\begin{tabular}{|c|c|c|c|}
\hline \multirow{2}{*}{ Variabel } & \multicolumn{2}{|c|}{ Kelompok Sampel } & \multirow{2}{*}{ Nilai p } \\
\hline & Bupivakain + Deksametason & Bupivakain & \\
\hline $\begin{array}{l}\text { Usia (tahun) } \\
\text { Mean } \pm \text { SD } \\
\text { Median } \\
\text { Range }\end{array}$ & $\begin{array}{c}34,25(13,84) \\
34 \\
40\end{array}$ & $\begin{array}{c}31(12,58) \\
28,5 \\
38\end{array}$ & 0,54 \\
\hline $\begin{array}{l}\text { Tingkat pendidikan } \\
\text { SD } \\
\text { SMP } \\
\text { SMU } \\
\text { S1 }\end{array}$ & $\begin{array}{l}3 \\
3 \\
5 \\
5\end{array}$ & $\begin{array}{l}1 \\
3 \\
9 \\
3\end{array}$ & 0,45 \\
\hline $\begin{array}{l}\text { Tinggi badan }(\mathrm{cm}) \\
\text { Mean } \pm \mathrm{SD} \\
\text { Median } \\
\text { Range }\end{array}$ & $\begin{array}{c}163(6,79) \\
162,5 \\
23\end{array}$ & $\begin{array}{c}163,75(6,15) \\
164,5 \\
19\end{array}$ & 0,75 \\
\hline $\begin{array}{l}\text { Berat badan }(\mathrm{kg}) \\
\text { Mean } \pm \mathrm{SD} \\
\text { Median } \\
\text { Range }\end{array}$ & $\begin{array}{c}59,19(8,06) \\
57,5 \\
27\end{array}$ & $\begin{array}{c}58,31(9,03) \\
57,5 \\
30\end{array}$ & 0,77 \\
\hline $\begin{array}{l}\text { Lama operasi (menit) } \\
\text { Mean } \pm \text { SD } \\
\text { Median } \\
\text { Range }\end{array}$ & $\begin{array}{c}184(65,01) \\
182,5 \\
232\end{array}$ & $\begin{array}{c}178,81(79,09) \\
150 \\
253\end{array}$ & 0,84 \\
\hline
\end{tabular}

ekstremitas bawah. Subjek penelitian dibagi atas 2 kelompok yang terdiri atas 16 subjek kelompok kombinasi deksametason $5 \mathrm{mg}$ dan bupivakain 0,5\% serta 16 subjek kelompok bupivakain 0,5\% murni. Karakteristik umum kedua kelompok perlakuan berdasarkan usia, tingkat pendidikan, tinggi badan, berat badan, dan lama operasi tidak didapatkan perbedaan bermakna ( $p>0,05$; Tabel 1$)$.

Mula kerja blok untuk kelompok bupivakain dan deksametason didapat rata-rata sebesar 13,56 menit dengan standar deviasi 4,72 menit, median sebesar 12,5 menit, dan range sebesar 19 menit. Untuk kelompok bupivakain didapat rata-rata sebesar 14,31 menit dengan standar deviasi 3,00 menit, median sebesar 14 menit, dan range sebesar 10 menit. Menurut analisis statistika mempergunakan Uji Mann-
Whitney karena syarat normalitas yang tidak terpenuhi, didapat mula kerja kedua kelompok penelitian tidak bermakna secara statistika ( $>$ >0,05; Tabel 2; Gambar 1).

Lamakerjablokuntuk kelompokbupivakain dan deksametason didapat rata-rata sebesar 399,81 menit dengan standar deviasi sebesar 137,90 menit, median sebesar 355,5 menit, dan range sebesar 534 menit. Untuk kelompok bupivakain didapat rata-rata sebesar 227,44 menit dengan standar deviasi sebesar 40,02 menit, median sebesar 213 menit, dan range sebesar 170 menit. Berdasarkan uji statistika dengan mempergunakan Uji Mann-Whitney karena syarat normalitas yang tidak terpenuhi, maka didapat lama kerja blok kedua kelompok bermakna secara statistika $(\mathrm{p}<0,05$; Tabel 3; Gambar 2).

Tabel 2 Karakteristik Mula Kerja Blok Epidural

\begin{tabular}{lccc}
\hline \multirow{2}{*}{$\begin{array}{c}\text { Mula Kerja Blok } \\
\text { (menit) }\end{array}$} & \multicolumn{2}{c}{ Kelompok Sampel } & Nilai p \\
\cline { 2 - 3 } & $\begin{array}{c}\text { Bupivakain }+ \\
\text { Deksametason }\end{array}$ & Bupivakain & 0,27 \\
Mean \pm SD & $13,56(4,72)$ & $14,31(3,00)$ & 14 \\
Median & 12.5 & 10 & \\
Range & 19 & 10 & \\
\hline
\end{tabular}




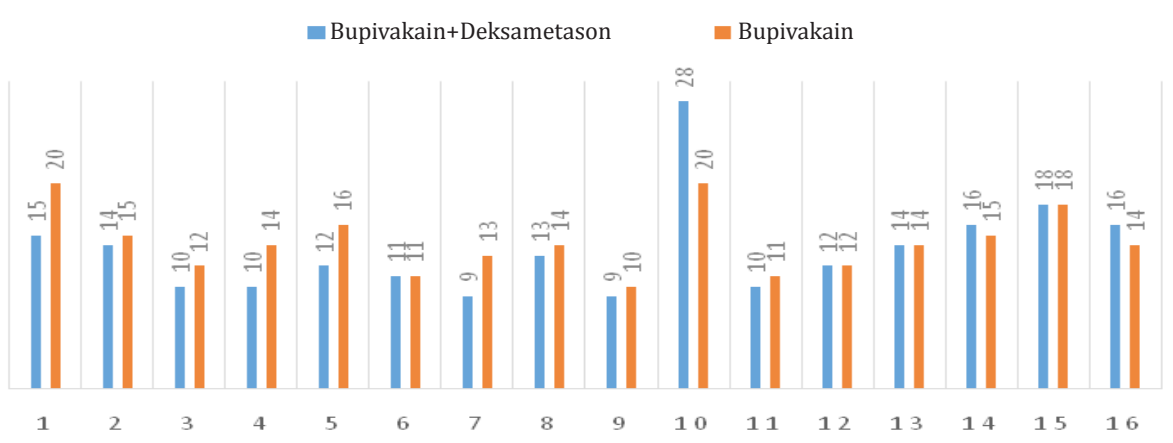

Gambar 1 Grafik Mula Kerja Blok (Menit)

\section{Pembahasan}

Terdapat beberapa cara yang dipergunakan untukmempercepat mula kerja dan menambah lama kerja blokade sensorik dan juga motorik obat anestesia lokal yang dipergunakan pada anestesia epidural. Baik dengan meningkatkan dosis obat anestesia lokal maupun dengan penambahan obat lainnya (adjuvan) ke dalam obat anestesia lokal tersebut. Peningkatan dosis obat anestesia lokal yang dipergunakan dibatasi oleh kemungkinan terjadi toksisitas sistemik yang makin besar pula. Telah banyak dilakukan penelitian mengenai penambahan adjuvan ke dalam obat anestesia lokal guna memperbaiki kualitas kerja blokade anestesia lokal dengan melihat juga efek samping yang dihasilkan dari pemakaian adjuvan yang harus minimal dan tidak berdampak baru bagi pasien. Pada penelitian ini dipergunakan penambahan adjuvan deksametason ke dalam obat anestesi lokal bupivakain guna memperbaiki kualitas blokade sensorik bupivakain yang digunakan untuk anestesi epidural.

Mula kerja blok sensorik anestesia epidural terhadap kelompok kombinasi deksametason $5 \mathrm{mg}$ dan bupivakain $0,5 \%$ yaitu 13,56 $(4,71)$ menit dibanding dengan kelompok bupivakain $0,5 \%$ murni yaitu $14,31(3,00)$ menit yang secara statistika perbedaan ini tidak bermakna $(p>0,05)$. Meskipun secara statistika tidak berbeda bermakna, namun secara klinis terdapat perbedaan mula kerja pada kedua kelompok perlakuan. Hasil yang tidak bermakna secara statistika mungkin dikarenakan jumlah sampel yang kurang.

Lama kerja blokade sensorik lebih panjang pada kelompok kombinasi deksametason $5 \mathrm{mg}$ dan bupivakain 0,5\%, yaitu 399,81 $(137,90)$ menit. Lama kerja kelompok bupivakain 0,5\% murni, yaitu 227,43 $(40,01)$ menit yang secara statistika bermakna $(p<0,05)$.

Deksametason mempercepat mula/onset kerja melalui efek anti-inflamasi yang kuat. Peningkatan dosis anestetik lokal dengan cara meningkatkan konsentrasi pada obat anestesi lokal akan mempercepat mula kerja blokade sensorik dan juga motorik. Hal ini disebabkan jumlah obat anestesia lokal yang menembus membran saraf bertambah. ${ }^{6-9}$

Tabel 3 Karakteristik Lama Kerja Blok Epidural

\begin{tabular}{lccc}
\hline \multirow{2}{*}{$\begin{array}{c}\text { Lama Kerja Blok } \\
\text { (menit) }\end{array}$} & \multicolumn{2}{c}{ Kelompok Sampel } & \multirow{2}{*}{ Nilai p } \\
\cline { 2 - 3 } & Bupivakain + Deksametason & Bupivakain & \\
\hline Mean \pm SD & $399,81(137,90)$ & $227,44(40,02)$ & 0,00 \\
Median & 355,5 & 213 & \\
Range & 534 & 170 & \\
\hline
\end{tabular}




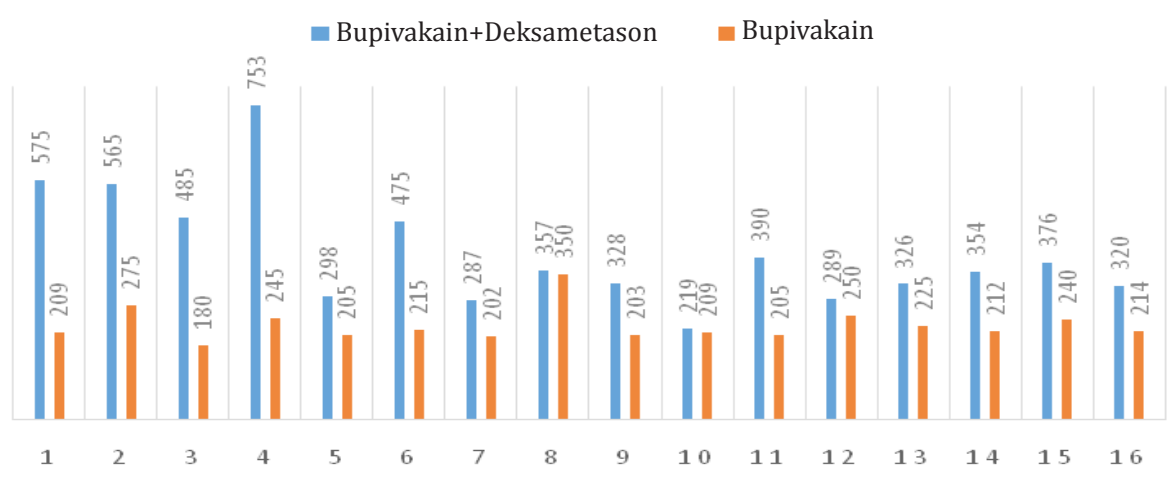

Gambar 2 Grafik Lama Kerja Blok (Menit)

Mekanisme lain adalah menghambat secara lokal penghantaran impuls serabut saraf $\mathrm{C}$ tidak bermielin karena kortikosteroid bekerja memengaruhi kecepatan sintesis membran lipoprotein sel saraf. Molekul kortikosteroid memasuki sel kemudian melewati membran plasma dengan cara difusi pasif. Kortikosteroid ini bereaksi dengan reseptor protein yang spesifik dalam sitoplasma sel dan membentuk kompleks reseptor steroid. Kompleks ini mengalami perubahan formasi, lalu bergerak menuju nukleus dan akan berikatan dengan kromatin. Ikatan ini menstimulasi transkripsi RNA dan juga sintesis protein spesifik. Induksi sintesis protein ini akan menghasilkan efek fisiologi steroid. ${ }^{8-11}$

Hal lainnya yang membuat deksametason mempercepat mula kerja obat anestesia lokal adalah efek deksametason sebagai anestetik lokal yang bekerja dengan cara menghambat potensial aksi serabut saraf C. Penelitian lain menyatakan bahwa aksi kortikosteroid pada reseptor di medula spinalis akan memblokade aktivitas di kornu dorsalis yang ditimbulkan oleh serabut saraf tipe C. ${ }^{10-12}$

Mekanisme kerja deksametason dalam memperpanjang lama kerja bupivakain pada anestesia epidural adalah melalui penurunan pelepasan bradikinin, tumor necrosis factor, interleukin-1, interleukin-2, interleukin-6, dan juga penurunan produksi prostaglandin. Penurunan prostaglandin berperanan dalam menghambat nyeri melalui penekanan sistem siklooksigenasi 1 dan juga 2 di jaringan perifer serta sistem saraf pusat. ${ }^{9,11,12}$

Steroid endogen merupakan bagian dari pertahanan tubuh terhadap hal yang merusak sel tubuh. Respons pusat terhadap peradangan adalah peningkatan sintesis sitokin sehingga akan mengaktifkan jalur hipotalamus pituitari adrenal yang mengakibatkan peningkatan sintesis glukokortikoid. Glukokortikoid akan menekan ekspresi sitokin yang bekerja pada sel target dengan cara melakukan umpan balik negatif, selanjutnya glukokortikoid ini bekerja sebagai imunosupresan terhadap berbagai reaksi dalam sistem imun. ${ }^{8-10}$

Pada tingkat molekuler, glukokortikoid berinteraksi dengan reseptor kompleks ligan. Efek terapi, anti-inflamasi, dan imunosupresan dari glukokortikoid dimediasi oleh berbagai jalur. Gen yang membawa kode protein antiinflamasi, seperti lipokortin, interleukin-1, antagonis reseptor, serta secretory leucocyte protease inhibitor akan mengalami stimulasi oleh reseptor glukokortikoid melalui interaksi glukokortikoid dengan deoxyribonucleic acid (DNA). Sebaliknya, gen yang mengekspresikan protein proinflamasi seperti sitokin serta kemokin akan ditekan akibat interaksi reseptor glukortikoid sebagai monomer dengan subunit transkripsi gen untuk protein ini. 6,7,7,10 $^{2}$

Respons inflamasi, metabolik, hormonal, dan imunologik akibat proses pembedahan akan diaktifkan segera pada saat insisi kulit sehingga pemberian kortikosteroid pada saat 
preoperatif penting untuk mendapatkan efek menguntungkan kortikosteroid selama dan juga pada saat setelah operasi. Deksametason terbukti sangat menguntungkan menurunkan respons ini karena efek anti-inflamasi serta imunosupresif., 90

Efek langsung penggunaan kortikosteroid yang diaplikasikan secara lokal pada serabut saraf yang diberikan rangsangan elektrik membuktikan bahwa kortikosteroid menekan transmisi impuls pada serabut saraf tipe C yang tidak bermielinisasi. Serabut saraf tipe ini berperanan dalam penghantaran impuls nyeri (nosiseptik). Efek tersebut berlangsung hingga kortikosteroid tersebut dihilangkan. ${ }^{8-12}$

Sinergi antara deksametason dan anestestik lokal yang disebabkan oleh karena efek antiinflamasi serta imunosupresif, dikarenakan juga oleh efek vasokonstriksi deksametason akibat proses migrasi sel-sel inflamasi itu dan juga asidosis lokal pada sel saraf yang menyebabkan anestetik lokal yang terionisasi semakin banyak dan terperangkap dalam sel saraf. Kortikosteroid bekerja juga dengan memengaruhi kecepatan sintesis protein, ikatan dengan protein itu menentukan lama kerja obat anestesia lokal. Hal ini disebabkan oleh semakin tinggi ikatannya dengan protein maka akan semakin lama pula obat anestesi lokal tinggal di dalam membran lipoprotein sel saraf. ${ }^{7,9-11}$

\section{Simpulan}

Berdasarkan pengujian hasil penelitian dan pembahasan maka dapat disimpulkan bahwa penambahan deksametason $5 \mathrm{mg}$ dalam bupivakain 0,5\% memperpanjang lama kerja blokade sensorik anestesia epidural tetapi tidak mempercepat mula kerja/onset blokade sensorik anestesia epidural.

Deksametason $5 \mathrm{mg}$ dapat digunakan sebagai salah satu alternatif adjuvan untuk memperpanjang lama kerja anestesia epidural.

\section{Daftar Pustaka}

1. Desboroug JP. The stress response to trauma and surgery. Br J Anaesth. 2000;
85(1):109-17.

2. ChandrasekharS,Smith MC.Spinal, epidural and caudal anesthesia. Dalam: Hurford WE, Bailin MT, Davison JK, penyunting. Clinical anesthesia procedures of the Massachusetts General Hospital. Edisi ke6. Philadelphia: Lippincott Williams and Wilkins Co. 2002. hlm. 231-52.

3. Viscomi CM. Pharmacology of local anesthetic. Dalam: Rahmell JP, Neal JM, Viscomi CM, penyunting. Regional anesthesia; the requisites in anesthesiology. Edisi ke-1. Philadelphia: Elseiver; 2004. hlm. 13-24.

4. Stoelting RK, Hillier SC. Local anesthetic. Dalam: Brown B, Murphy F, penyunting. Pharmacology and physiology in anesthetic practice. Edisi ke-4. Philadelphia: Lippincott Williams and Wilkins Co; 2006. hlm. 179-207.

5. Haddad T, Min J. Local anesthetic. Dalam: Hurford WE, Bailin MT, Davison JK, penyunting. Clinical anesthesia procedures of the Massachusetts General Hospital. Edisi ke-6. Philadelphia: Lippincott Williams and Wilkins Co; 2002. hlm. 22030.

6. Salerno A, Herman, R. Efficacy and safety of steroid use for post operative pain relief. J Bone Joint Surg Am. 2006;88(6):1361-72.

7. Kopacz DJ, Lacouture PG. The dose response and effects of dexamethasone on bupivacaine $\left(\mathrm{T}_{9}-\mathrm{T}_{11}\right)$ in healthy volunters. Anesth Analg. 2003;96:576-82.

8. Aisha B, Rajpreet B. The mechanism of action and side effects of epidural steroids. J Techniques Regional Anesthesia Pain Management. 2009;13:205-11.

9. Suherman SK, Ascobat P. Adrenokortikotropin, adrenokrotikosteroid, analog sintetik dan antagonisnya. Dalam: Gunawan GS, penyunting. Farmakologi. Edisi ke-5. Jakarta: FKUI; 2009. hlm. 496516.

10. Khafagy HF, Refaat AI, El-Sabae HH, Youssif MA. Efficacy of epidural dexamethasone versus fentanyl on postoperative analgesia. J Anesth. 2010;24:531-6.

11. Nadia BH, Bahman HN, Ebrahim AP, Parviz 
116 | Jurnal Anestesi Perioperatif

AM, Aliakbar N, Ali J. Addition of intrathecal dexamethasone to bupivacaine for spinal anesthesia in orthopedic surgery. Saudi J Anaesth. 2011;5:382-6.
12. Movafegh A, Razazian M. Dexamethasone added to lidocaine prolongs axillary brachial plexus blockade. Anesth Analg. 2006;102:263-7. 